\title{
The Persistence of Chlamydia trachomatis Elementary Body Cell Walls in Human Polymorphonuclear Leucocytes and Induction of a Chemiluminescent Response
}

\author{
By MENACHEM ZVILLICH AND ISRAEL SAROV* \\ Virology Unit, Faculty of Health Sciences, and Soroka University Hospital, \\ Ben-Gurion University of the Negev, Beer Sheva, Israel
}

(Received 11 February 1988; revised 13 July 1988; accepted 17 October 1988)

\begin{abstract}
Human polymorphonuclear leucocytes (HPMN) were incubated with [ ${ }^{35}$ S $]$ methionine-labelled Chlamydia trachomatis (serovar L2/434/Bu) elementary bodies (EB) and EB cell walls. No net loss in the TCA-precipitable radioactivity was observed over $24 \mathrm{~h}$ in the HPMN that had taken up EB cell walls. SDS-polyacrylamide gel electrophoresis of the labelled $C$. trachomatis $\mathrm{EB}$ and EB cell wall proteins extracted from the HPMN at 2 and $24 \mathrm{~h}$ after infection demonstrated the persistence of most of the chlamydial cell wall polypeptides. Analysis of extracts of the HPMN that had taken up either EB or EB cell walls on Urografin density gradients at 2 and $24 \mathrm{~h}$ after infection, and electron microscopic observations on fractions representing the peaks, demonstrated the persistence of the EB cell walls in the HPMN. Electron microscopic observations of HPMN that had taken up EB or EB cell walls demonstrated EB cell walls in the HPMN phagosomes at $24 \mathrm{~h}$ after infection. The HPMN exposed to EB and EB cell walls of $C$. trachomatis gave chemiluminescent (CL) responses with peaks respectively 12 and 7 times greater than the peak value of the control. The significance of the persistence of the EB cell wall polypeptides and cell walls in the HPMN and activation of the HPMN to produce oxygen radicals (i.e. a CL response), and its possible relation to rheumatic diseases, is discussed.
\end{abstract}

\section{INTRODUCTION}

Chlamydia trachomatis is an obligate intracellular Gram-negative bacterium with a genome of $660 \times 10^{6} \mathrm{Da}$ (Sarov \& Becker, 1969; Moulder, 1982). A total of 15 serovars of $C$. trachomatis have been described which cause hyperendemic trachoma (serovars $\mathrm{A}, \mathrm{B}, \mathrm{Ba}$ and $\mathrm{C}$ ) in developing countries and sexually transmitted infections (serovars $D$ to $K$ ) such as nongonococcal urethritis, cervicitis, endometritis, salpingitis, perihepatitis, epididymitis, conjunctivitis and pneumonia. The three serovars L1, L2 and L3 cause lymphogranuloma venereum (reviewed by Ladany \& Sarov, 1985). Considerable evidence has been accumulated regarding the possible role of chlamydiae in the pathogenesis of arthritis and other rheumatic diseases (reviewed by Keat, 1986). Recently, typical chlamydial elementary bodies (EB) were seen in joint material from patients with different sexually acquired non-gonococcal genital-tract infections (Keat et al., 1987) and in the synovial tissue of a patient with Reiter's syndrome (Ishikawa et al., 1986). Approximately $5 \%$ of patients with lymphogranuloma venereum develop a remitting large-joint arthritis, with a higher proportion experiencing polyarthralgia and erythema nodosum (Abrams, 1968). In cattle and sheep, systemic chlamydial infection has frequently been associated with polyarthritis. In this condition chlamydiae are demonstrated

\footnotetext{
Abbreviations : CL, chemiluminescence; EB, elementary bodies; HBSS, Hanks' balanced salt solution; HPMN, human polymorphonuclear leucocytes; IFU, inclusion-forming units; MOMP, major outer-membrane protein; PLF, phagosome-lysosome fusion; PMA, phorbol 12-myristate 13-acetate.
} 
within the joint, at least initially, although subsequently synovitis may persist without detectable micro-organisms (Storz, 1967).

Several models have been proposed to explain the development of chronic arthritic diseases (Ginsburg, 1977). Ginsburg \& Lahav (1983) suggested that while 'professional phagocytes' possess bactericidal and bacteriolytic factors capable of killing and depolymerizing the complex cellular constituents of bacteria, certain micro-organisms possess surface and wall components which are extremely resistant to degradation by serum complement, polymorphonuclear leucocytes (PMN) and macrophages. This may, under certain conditions, trigger active release of lysosomal enzymes which may cause inflammatory responses, tissue destruction and rheumatoid arthritis. Cell wall components of streptococci and staphylococci have been shown to trigger chronic destructive arthritis in laboratory animals (reviewed by Ginsburg, 1979). An additional hypothesis was recently put forward on the role of superoxide and oxygen radicals released by activated human PMN (HPMN) (Quie et al., 1977), in the development of chronic (Fanburg et al., 1986), arthritic (Biemond et al., 1986; Lunec et al., 1981; Pasquier et al., 1984) and neoplastic diseases (Cerutti, 1985). Superoxide anions $\left(\mathrm{O}_{2}^{-}\right)$and related oxygen radicals $\left(\mathrm{O}_{2}^{1} \cdot{ }^{\circ} \mathrm{OH}\right)$ have been shown to oxidize biomembranes (Taffel, 1973), to depolymerize hyaluronic acid (Babior, 1978), and to serve as effectors of cartilage destruction (Burkhardt et al., 1986; Keiser, 1980). Furthermore, these active molecules could denature IgG molecules in tryptophan-rich areas of the molecule, leading to generation of IgG complexes detected in the joint fluid of patients with rheumatoid arthritis (Lunec \& Hill, 1984). ${ }^{\circ} \mathrm{O}_{2}^{-}$has also been shown to participate in the formation of a potent chemoattractant (Petrone et al., 1980), thereby raising the concentration of HPMN in the synovial cleft (Mohr et al., 1981). HPMN have been shown to be the predominant inflammatory cells which infiltrate the site of chlamydial infection (Kunimoto \& Brunham, 1985; Monnickendam \& Pearce, 1983; Monnickendam et al., 1980; Woodland \& Darougar, 1986). EB of $C$. trachomatis have been shown to activate complement and to stimulate chemotaxis (Megran et al., 1985).

In the present study the fate of the EB (L2/434/Bu) of C. trachomatis in HPMN at various times after infection was studied by using SDS-polyacrylamide gel electrophoresis (SDS-PAGE) and Urografin gradients (employing [ ${ }^{35}$ S]methionine labelled EB and EB cell walls) and by electron microscopy. The ability of the EB and EB cell walls to activate the HPMN oxygen burst to produce superoxide anions $\left(\mathrm{O}_{2}^{-}\right)$and related oxygen species was investigated by using the luminol-enhanced chemiluminescence $(\mathrm{CL})$ assay.

\section{METHODS}

Growth conditions, radiolabelling and purification of chlamydial EB. EB of C. trachomatis biotype lymphogranuloma venereum (L2/434/Bu) were grown on BGM cells (Flow Laboratories) and purified 48-72 h postinfection by modification of the method of Caldwell et al. (1981) as previously described (Zvillich \& Sarov, 1985). Radiolabelling of $C$. trachomatis EB was performed in chlamydial growth medium containing $20 \mathrm{mM}$ instead of $100 \mathrm{mM}$-methionine, and $10 \mu \mathrm{Ci}\left[{ }^{35} \mathrm{~S}\right] \mathrm{methionine} \mathrm{ml}^{-1}\left(500 \mu \mathrm{Ci} \mathrm{mmol}^{-1} ; 18.5 \mathrm{MBq} \mathrm{mmol}^{-1}\right.$; Amersham). For the $\mathrm{CL}$ assay and Urografin gradient experiments, EB were washed by centrifugation $\left(43000 \mathrm{~g}, 45 \mathrm{~min}, 4^{\circ} \mathrm{C}\right.$ in an SW-28 rotor), resuspended in Hanks' balanced salt solution (HBSS; Biological Industries, Beth Haemek, Israel) and sonicated for $20 \mathrm{~s}$ in a Bransonic B-12 sonifier.

Immunoperoxidase assay for titration of C. trachomatis. C. trachomatis was titrated on BGM cells as described by Shemer \& Sarov (1984). The final results of the titration were expressed as inclusion-forming units (IFU) $\mathrm{ml}^{-1}$.

Preparation and radiolabelling of chlamydial EB cell walls. Cell walls of $C$. trachomatis were prepared by the method of Jenkin (1960). Levy \& Moulder (1982) showed that envelopes prepared in this way retained some native activity with respect to their ability to attach to susceptible host cells. EB of $C$. trachomatis were suspended in $0.01 \mathrm{M}$-sodium phosphate buffer ( $\mathrm{pH} 7.4)$ containing $1 \%(\mathrm{v} / \mathrm{v})$ sodium deoxycholate (Sigma) and shaken for $4 \mathrm{~h}$ at $45^{\circ} \mathrm{C}$. The detergent-treated organisms were centrifuged at $10000 \mathrm{~g}$ for $10 \mathrm{~min}$ in a Beckman SW-28 rotor, rinsed twice with $0.01 \mathrm{M}$-sodium phosphate buffer (pH 7.4), incubated for $1 \mathrm{~h}$ at $37^{\circ} \mathrm{C}$ with $1 \mathrm{mg}$ crystalline trypsin $\mathrm{ml}^{-1}$ (Sigma), washed three times with phosphate-buffered saline and stored at $-70^{\circ} \mathrm{C}$. Protein content of the preparations was $1-1.5 \mathrm{mg} \mathrm{m}^{-1}$ and represented $10 \%$ of the starting material. Protein was determined by the BioRad protein assay kit, with bovine serum albumin as standard. The number of cell walls in a given volume was evaluated by titration of the number of viable EB in the starting material used for the cell wall preparation and protein determination. $\left.{ }^{35} \mathrm{~S}\right]$ Methionine-labelled EB cell walls of $C$. trachomatis were prepared by subjecting labelled EB to the procedure described above. 
Isolation of HPMN. This was done by the method of Boyum (1968). Heparinized whole blood was obtained from healthy human donors, diluted twofold with RPMI-1640 medium, layered onto Ficoll-Hypaque (Pharmacia; $1.077 \mathrm{~g} \mathrm{ml}^{-1}$ at $25^{\circ} \mathrm{C}$ ), and centrifuged at $400 \mathrm{~g}$ for $30 \mathrm{~min}$. The pellet was resuspended in an equal volume of $6 \%$ (v/v) dextran in RPMI-1640 medium. The erythrocytes were allowed to sediment at $37^{\circ} \mathrm{C}$ for $30 \mathrm{~min}$ and the HPMN-enriched supernate was removed and centrifuged for $5 \mathrm{~min}$ at $400 \mathrm{~g}$. Contaminating erythrocytes were removed by osmotic shock. The HPMN cells ( $99 \%$ pure) were washed three times and resuspended in RPMI-1640 containing $10 \%$ (v/v) foetal calf serum. For the CL assay, HPMN were suspended in HBSS without phenol red. The viability was $99 \%$ as determined by $1 \%$ trypan blue staining. After $24 \mathrm{~h}$ incubation, viability of the HPMN was $85 \%$.

Electrophoretic and TCA analysis of radiolabelled EB and EB cell walls in the HPMN. HPMN $\left(1.6 \times 10^{7}\right)$ were incubated for $2 \mathrm{~h}\left(37^{\circ} \mathrm{C}\right.$, in a humidified $5 \%, \mathrm{v} / \mathrm{v}, \mathrm{CO}_{2} /$ air mixture $)$ in $1.0 \mathrm{ml} \mathrm{RPMI}-1640$ medium containing $10 \%$ FCS, $50 \mu \mathrm{g}$ streptomycin ml ${ }^{-1}, 5 \mu \mathrm{g}$ gentamicin $\mathrm{ml}^{-1}$ and $8 \times 10^{7}$ radiolabelled EB or cell walls from $8 \times 10^{7} \mathrm{~EB}$ $(100 \mu \mathrm{g}$ protein). The HPMN were then washed three times by centrifugation $(400 \mathrm{~g}, 10 \mathrm{~min})$ with RPMI-1640 medium and further incubated at $37^{\circ} \mathrm{C}$ in a humidified $5 \%(\mathrm{v} / \mathrm{v}) \mathrm{CO}_{2} /$ air mixture, in a volume of $1 \mathrm{ml}$ of the same medium. At 2 and $24 \mathrm{~h}$ after the end of the infection period, samples $(250 \mu \mathrm{l})$ were solubilized by boiling in the presence of SDS and 2-mercaptoethanol and resolved on a $15 \%(\mathrm{w} / \mathrm{v})$ polyacrylamide slab gel with the discontinuous buffer system of Laemmli $\left(1970\right.$, using $\left[{ }^{14} \mathrm{C}\right]$ methylated protein size markers (Amersham). After SDS-PAGE, gels were treated with a solution containing $22 \%$ PPO, destained and dried under vacuum. Autoradiograms of dried gels were analysed by an LKB UltroScan XL laser densitometer. Also, samples $(250 \mu \mathrm{l})$ of HPMN 'infected' with EB cell walls, taken at 2 and $24 \mathrm{~h}$ after infection, were treated with $5 \%(\mathrm{w} / \mathrm{v})$ cold TCA on ice for $20 \mathrm{~min}$ and then transferred by filtration to glass-fibre filters (Schleicher \& Schüll GF/C filters) washed with $70 \%$ (v/v) ethanol, dried, put into scintillation fluid, and their radioactivity measured in a Packard Tri-Carb scintillation spectrophotometer, model 3310.

Urografin gradients and fractionation of infected HPMN samples. HPMN $\left(8 \times 10^{6}\right)$ were incubated for $2 \mathrm{~h}\left(37^{\circ} \mathrm{C}\right.$, in a humidified $5 \%, \mathrm{v} / \mathrm{v}, \mathrm{CO}_{2} /$ air mixture) in $1 \mathrm{ml} \mathrm{RPMI}-1640$ medium containing $10 \% \mathrm{FCS}, 100 \mu \mathrm{g}$ streptomycin $\mathrm{ml}^{-1}$ and $2 \mathrm{mM}$-L-glutamine, with ${ }^{35}$ S $]$ methionine-labelled EB $\left(4 \times 10^{7} \mathrm{IFU} \mathrm{ml^{-1 } )}\right.$ or cell walls from $4 \times 10^{7} \mathrm{~EB}$ $(50 \mu \mathrm{g}$ protein). The HPMN were then washed three times $(400 \mathrm{~g}, 5 \mathrm{~min})$ with RPMI-1640 medium and further incubated at $37{ }^{\circ} \mathrm{C}$ in a humidified $5 \%(\mathrm{v} / \mathrm{v}) \mathrm{CO}_{2} /$ air mixture, in a volume of $1 \mathrm{ml}$ of the same medium. At 2 and $24 \mathrm{~h}$ after the end of the infection period samples $(250 \mu \mathrm{l})$ of HPMN that had been incubated with EB or EB cell walls, and samples of EB or cell walls alone, were sonicated for $20 \mathrm{~s}$ in a Bransonic-B 12 sonifier. The samples were loaded on $20-65 \%(\mathrm{v} / \mathrm{v})$ continuous Urografin gradients [solutions containing meglumine diatrizoate and sodium diatrizoate $76 \%$ for injection (Schering) in $0.01 \mathrm{M}$-HEPES buffer $\mathrm{pH} 7.2$, containing $0.15 \mathrm{M}-\mathrm{NaCl}$ ] and then centrifuged at $43000 \mathrm{~g}$ for $16-18 \mathrm{~h}$ at $4{ }^{\circ} \mathrm{C}$ in a Beckman SW-28 rotor. Fractions were collected, treated with $5 \%$ cold TCA on ice for $20 \mathrm{~min}$ and then transferred by filtration to GF/C glass-fibre filters, washed with $70 \%$ ethanol, dried, put into scintillation fluid and counted. Fractions representing the peaks obtained after Urografin gradientcentrifugation as described above were also observed by electron microscopy: fractions were diluted, sedimented by centrifugation $(10000 \mathrm{~g}, 20 \mathrm{~min}$ in Beckman SW-28 rotor), suspended in PBS, mounted on a carbon-coated grid, stained with $1 \%(w / v)$ uranyl acetate and observed.

Preparation for thin-section electron microscopy. Samples were prepared according to the method of Biberfeld (1971), as previously described (Zvillich \& Sarov, 1985). Electron micrographs of thin section were taken with a Philips $201 \mathrm{C}$ transmission electron microscope.

Chemiluminescence assay. Luminol-enhanced CL was measured by a modified procedure of Trush et al. (1978), in a liquid scintillation counter (Packard Tri-Carb liquid scintillation spectrometer, model 3310) kept at ambient temperature (approx. $23 \pm 1{ }^{\circ} \mathrm{C}$ ) and set 'out of coincidence' in the tritium mode. Samples for the CL assay were prepared by adding $0.8 \mathrm{ml}$ HBSS without phenol red and without antibiotics, containing $2 \mu \mathrm{M}$-luminol (5-amino2,3-dihydro-1,4-phthalazinedione; Sigma), $0.1 \mathrm{ml}$ cell suspension $\left(10^{6} \mathrm{HPMN}\right)$ and $0.1 \mathrm{ml}$ EB or EB cell wall suspension to sterile, disposable, $4 \mathrm{ml}$ polypropylene tubes $(38 \times 12.5 \mathrm{~mm}$; Nunc). The tubes (dark adapted for $24 \mathrm{~h}$ before the assay) were put into glass vials and placed in the scintillation counter, and the light emission was recorded for 0.2 min at intervals of 6-10 min. Zymosan and PMA (phorbol 12 myristate 13-acetate; Sigma) were used as controls and were prepared as previously described (Zvillich \& Sarov, 1985). The specificity of the assay was controlled by addition of $400 \mathrm{U}$ superoxide dismutase $\mathrm{ml}^{-1}$ (EC 1.15.1.1; Sigma) to the reaction mixture containing activated HPMN.

\section{RESULTS}

Fate of ${ }^{35}$ S]methionine-labelled $E B$ and $E B$ cell wall polypeptides in the HPMN

HPMN were incubated with $\left[{ }^{35} S\right]$ methionine-labelled EB cell walls of $C$. trachomatis at a ratio of $1: 5$. In both cases at $2 \mathrm{~h}$ following absorption, about $30 \%$ of the TCA-precipitable 

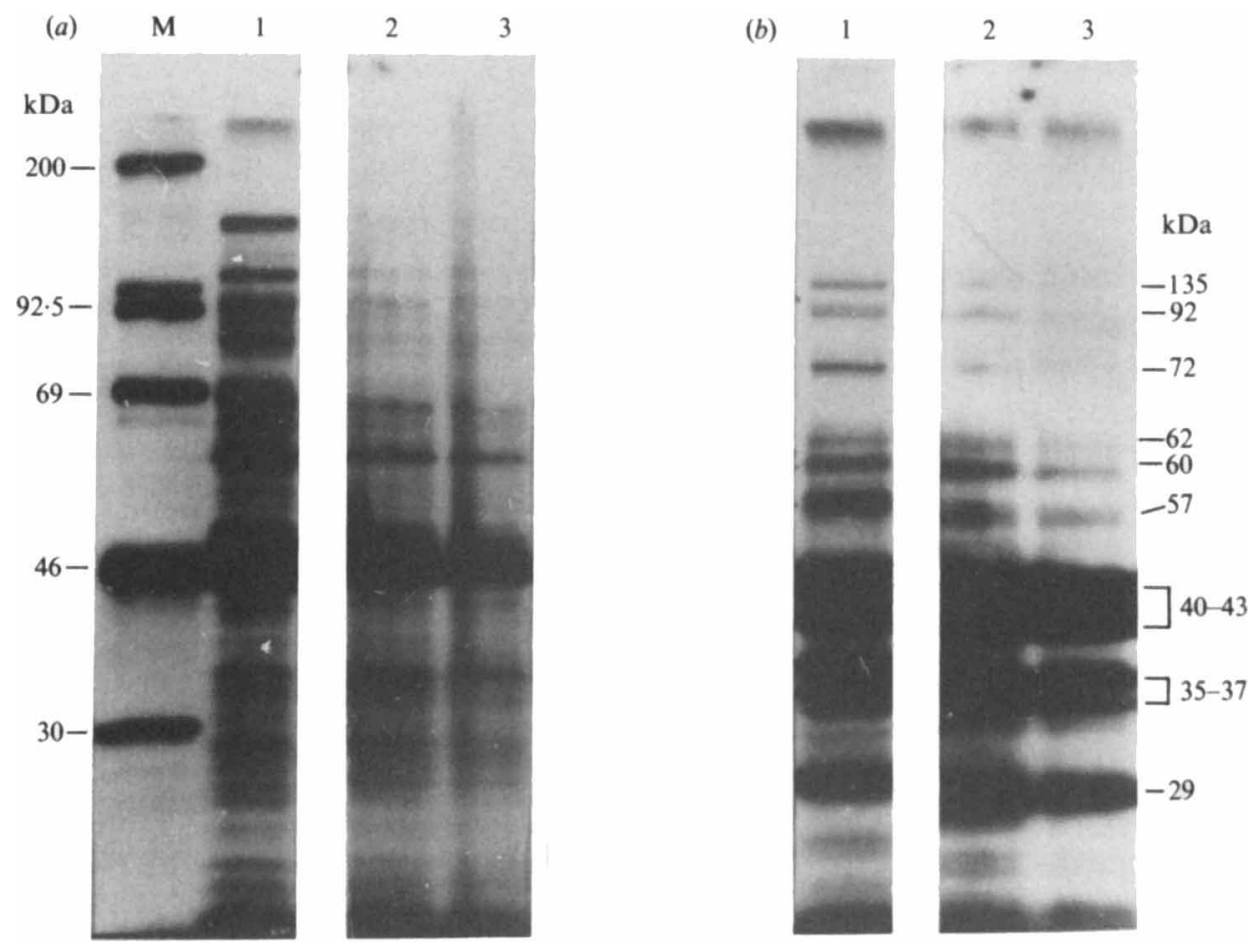

Fig. 1. SDS-PAGE of [ ${ }^{35}$ S $]$ methionine-labelled EB $(a)$ and EB cell walls $(b)$ of $C$. trachomatis extracted from the HPMN at $2 \mathrm{~h}$ (lanes 2) and $24 \mathrm{~h}$ (lanes 3 ) after infection. Lanes 1 contain EBs $(a)$ and EB cell walls $(b)$ alone. Molecular masses of EB cell wall polypeptides are marked on the right. M, molecular mass standards.

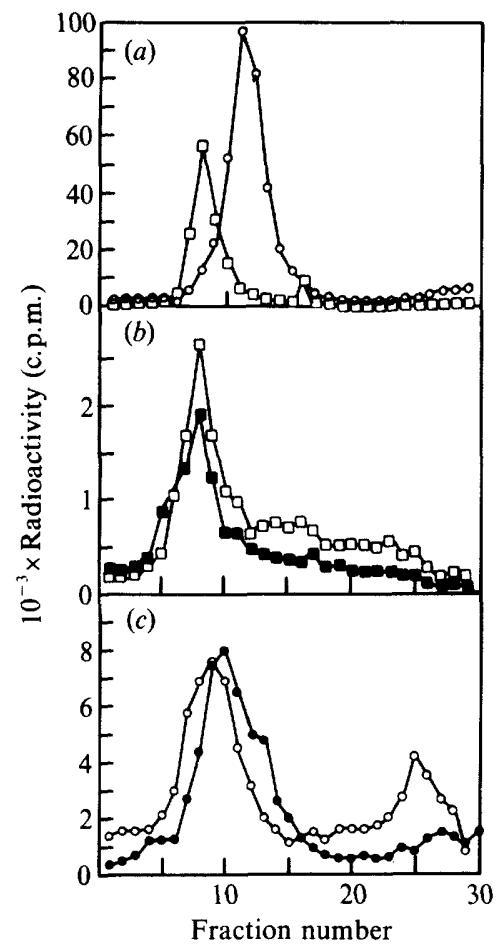

Fig. 2. Continuous $20-65 \%$ (v/v) Urografin density gradients loaded with: (a) $\left[{ }^{35} \mathrm{~S}\right]$ methioninelabelled EB $(O)$ and EB cell walls $(\square)$, serving as position standards for $(b)$ and $(c)$. (b) Extracts of HPMN 'infected' with EB cell walls. Samples taken at $2 \mathrm{~h}(\square)$ and $(\boldsymbol{C})$ after infection. (c) Extracts of HPMN infected with EB. Samples taken at $2 \mathrm{~h}(\mathrm{O})$ and $24 \mathrm{~h}(\mathrm{O})$ after infection. Samples were sonicated for $20 \mathrm{~s}$ and loaded on Urografin density gradients. Fractions were collected after centrifugation from the bottom (fraction no. 1) to the top (fraction no. 30). 

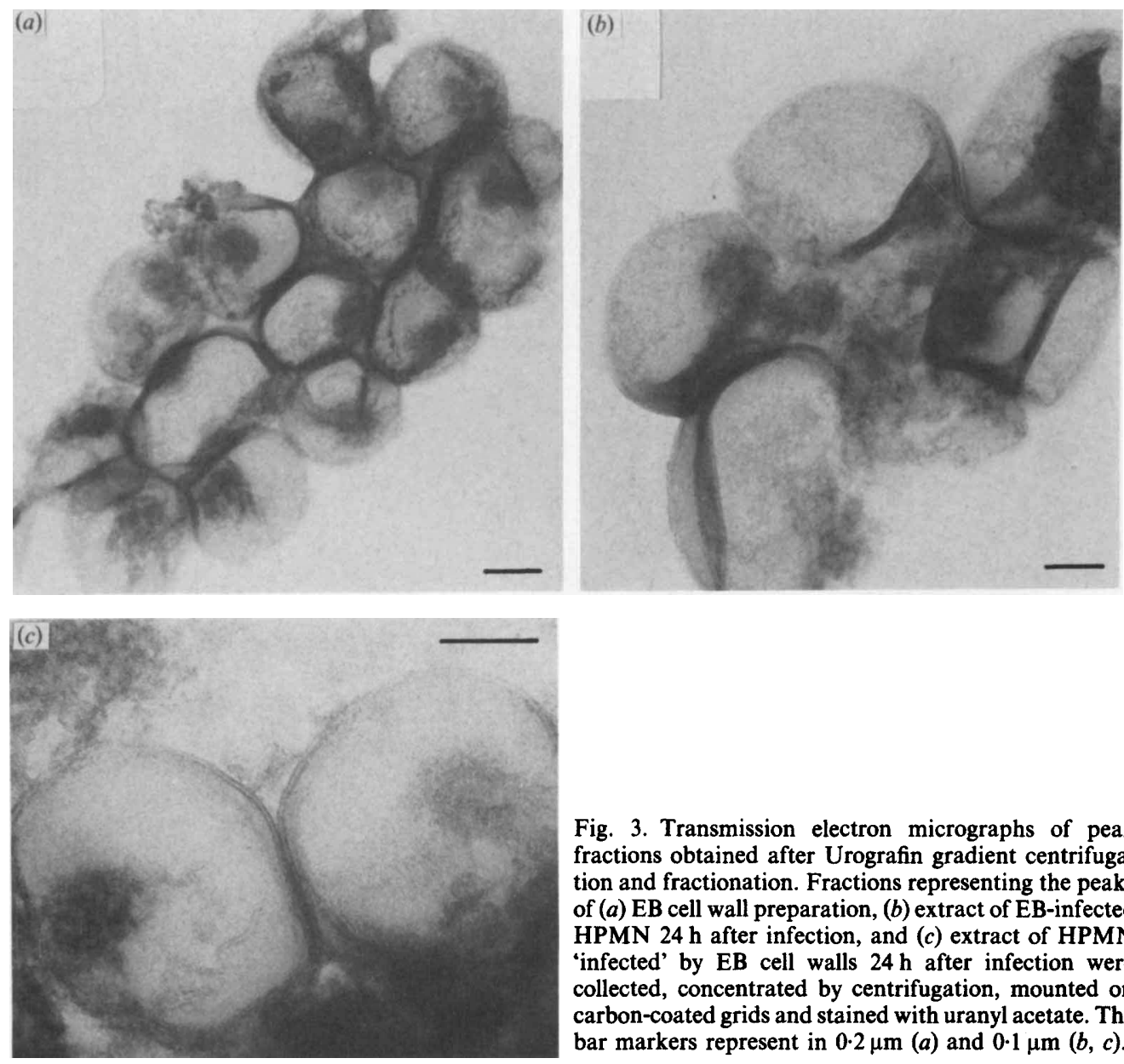

Fig. 3. Transmission electron micrographs of peak fractions obtained after Urografin gradient centrifugation and fractionation. Fractions representing the peaks of (a) EB cell wall preparation, (b) extract of EB-infected HPMN $24 \mathrm{~h}$ after infection, and (c) extract of HPMN 'infected' by EB cell walls $24 \mathrm{~h}$ after infection were collected, concentrated by centrifugation, mounted on carbon-coated grids and stained with uranyl acetate. The bar markers represent in $0.2 \mu \mathrm{m}(a)$ and $0.1 \mu \mathrm{m}(b, c)$.

radioactivity was associated with the $\mathrm{HPMN}$ while $70 \%$ was recovered in the medium. No significant net loss in TCA-precipitable radioactivity was observed in samples of HPMN 'infected' by EB cell walls at $24 \mathrm{~h}$ after 'infection' (for example: 13305 c.p.m. were detected in an HPMN sample $2 \mathrm{~h}$ after infection and 12820 c.p.m. were detected in a sample taken $24 \mathrm{~h}$ after infection).

The EB or EB cell wall polypeptides extracted from the HPMN 2 and $24 \mathrm{~h}$ after infection were examined by SDS-PAGE followed by autoradiography. Fig. 1 $(a, b)$ demonstrates the appearance of the $29,35-37,40-43 \mathrm{kDa}$ polypeptides [MOMPs: major outer-membrane proteins (Salari \& Ward, 1981)] and 57, 60, 62, 72, 92 and $135 \mathrm{kDa}$ polypeptides, in the HPMN at 2 and $24 \mathrm{~h}$. Densitometry scanning of autoradiograms indicated an insignificant change in the MOMPs (less than 3\%) while some differences (in the 5-10\% range) in the higher molecular mass polypeptides ( $\geqslant 57 \mathrm{kDa}$ ) occurred $24 \mathrm{~h}$ after infection.

Fig. 2 demonstrates that in continuous, 20-65\%, Urografin density gradients, $24 \mathrm{~h}$ after infection, the content of extracts of HPMN 'infected' by EB cell walls appeared in the same position as purified EB cell walls (position standard) (Fig. $2 a$ versus $2 b$ ), while the content of extracts of EB-infected HPMN appeared as a broad band in a position between those of EB alone and EB cell walls (Fig. $2 a$ versus Fig. $2 c$ ).

The content of fractions representing the peaks was also examined by electron microscopy (Fig. 3). Samples of EB-infected HPMN $24 \mathrm{~h}$ after infection contained predominantly EB cell 

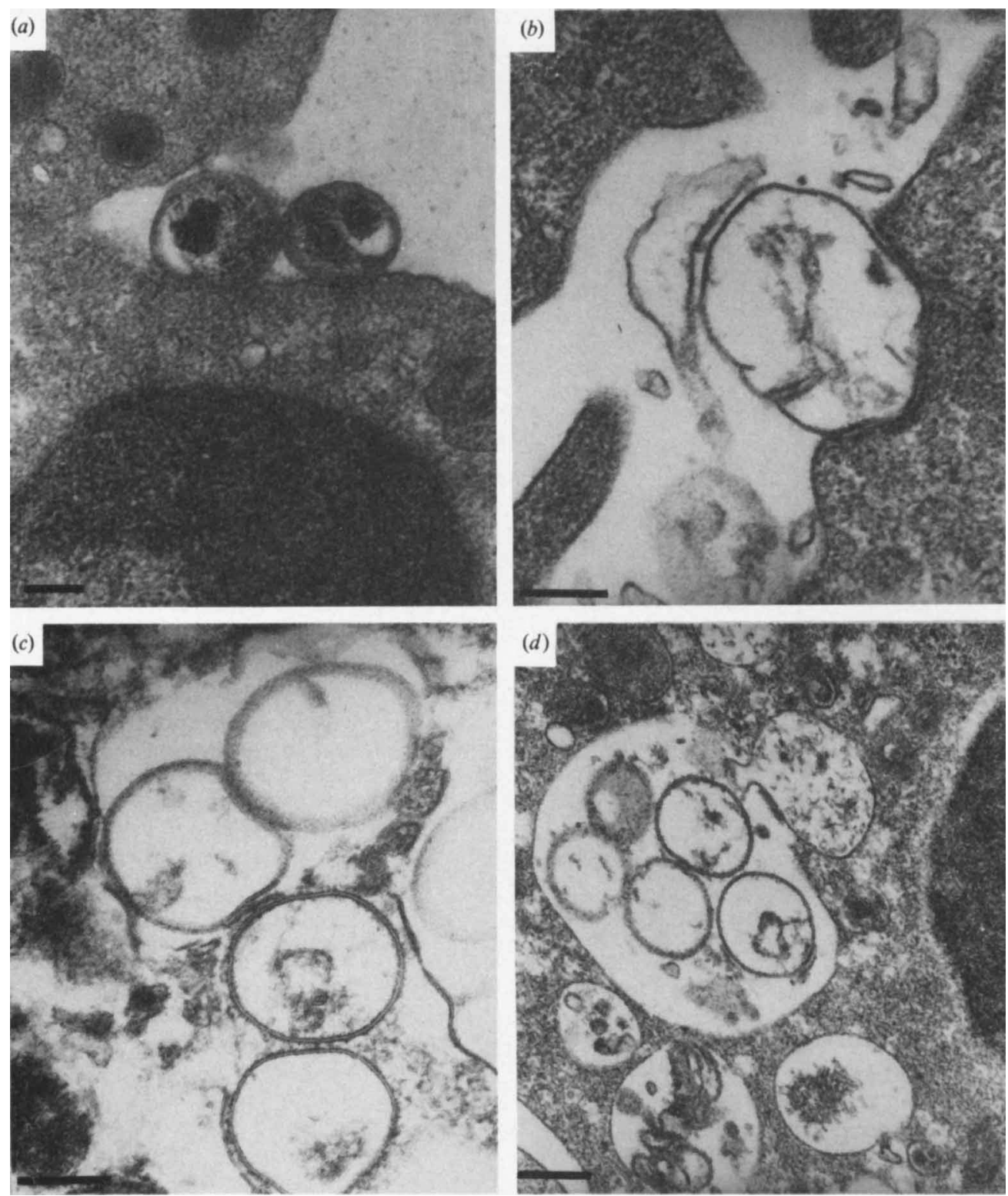

Fig. 4. Transmission electron micrographs of thin sections of HPMN infected with $C$. trachomatis EB and EB cell walls at a ratio of $1: 5$. $(a, b)$ Attachment of EB $(a)$ and EB cell walls $(b)$ to the HPMN cell membrane 30 min after infection. $(c, d)$ Cell walls in phagosomes of EB-infected HPMN $(c)$ and in HPMN 'infected' by EB cell walls $(d), 24 \mathrm{~h}$ after infection. The bar markers represent $0.2 \mu \mathrm{m}$.

walls (Fig. $3 b$ ) and occasionally EB, while EB cell walls (Fig. $3 c$ ) could be observed $24 \mathrm{~h}$ after infection in the samples of HPMN 'infected' by EB cell walls.

Electron microscopic observations of HPMN infected by C. trachomatis EB and EB cell walls HPMN were incubated with $C$. trachomatis $\mathrm{EB}$ and $\mathrm{EB}$ cell walls at a ratio of $1: 5$. Cells were fixed 30 min after infection. Attachment of EB (Fig. 4a) and EB cell walls (Fig. $4 b$ ) to the 


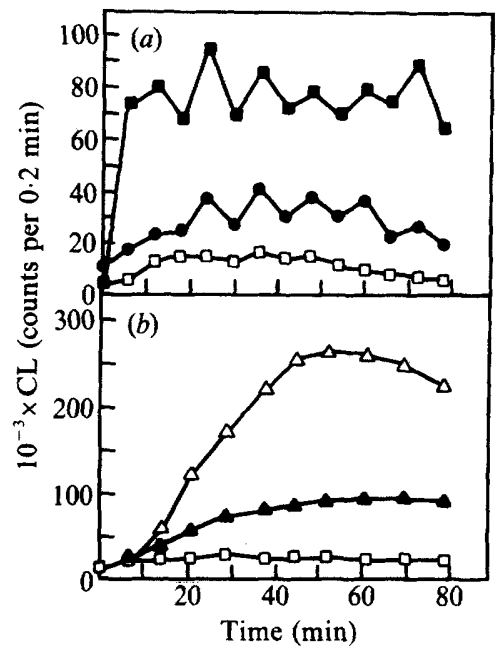

Fig. 5

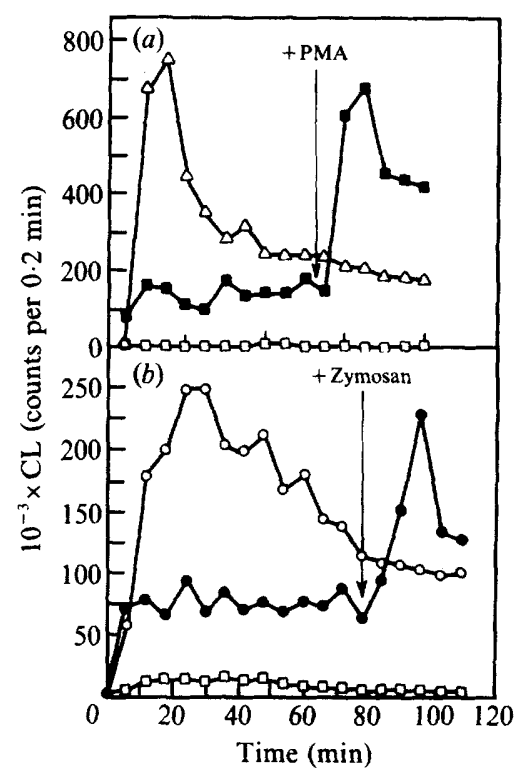

Fig. 6

Fig. 5. Luminol-enhanced CL response of $10^{6} \mathrm{HPMN}$ incubated $(a)$ in the presence of $C$. trachomatis EB cell walls at a ratio of $10(O)$ and $50(\square)$, and $(b)$ in the presence of EB at a ratio of $10(A)$ and $50(\triangle)$ [i.e. 10 or $50 \mathrm{~EB}$ IFU and about 10 or $50 \mathrm{~EB}$ cell walls (12 or $55 \mu \mathrm{g}$ protein) per cell]. The symbol $\square$ in (a) and $(b)$ represents HPMN without stimulant. The results represent one of three experiments that gave similar results.

Fig. 6. Luminol-enhanced CL response of $10^{6} \mathrm{HPMN}$, which were initially stimulated with $C$. trachomatis $\overline{\mathrm{E}} \overline{\mathrm{B}}$ cell walls (about 50 E Ë cell walls per HPMN), to PMA $(a)$ and Żymosan $(b)$. (a) PMA $\left(1 \mu \mathrm{g} \mathrm{ml}^{-1}\right)$ was added to the HPMN 60 min after stimulation with EB cell walls, (a). (b) Zymosan $\left(2 \mathrm{mg} \mathrm{m}^{-1}\right.$ ) was added to the HPMN $80 \mathrm{~min}$ after stimulation with EB cell walls $(O)$. The controls consisted of HPMN incubated with medium alone $(\square)$, with $1.0 \mu \mathrm{g}$ PMA ml-1 $(\triangle)$, or with $2.0 \mathrm{mg}$ Zymosan $\mathrm{ml}^{-1}(\mathrm{O})$. The results represent one of three experiments that gave similar results.

HPMN was observed. We (Zvillich \& Sarov, 1985), and Yong et al. (1986), have previously shown the partial degradation of chlamydial EB in HPMN after $2 \mathrm{~h}$ of incubation. In the present study we observed vacuoles in HPMN infected by either EB or EB cell walls, $24 \mathrm{~h}$ after infection, which contained cell walls (Fig. $4 c$ and $d$, respectively) and occasionally EB.

\section{Effect of C. trachomatis $E B$ and $E B$ cell walls on the luminol-enhanced $C L$ response of $H P M N$}

Incubation of HPMN with C. trachomatis EB cell walls or EB, in a ratio of $1: 10$ and $1: 50$, in both cases induced a marked CL response (Fig. $5 a, b$ ). Activity increased with an increase in the number of EB or EB cell walls. Peak activity was obtained after about 45 and $10 \mathrm{~min}$ of incubation respectively. A second stimulation of HPMN with PMA and Zymosan, after challenge with EB cell walls (Fig. 6), could be achieved, indicating the potential of HPMN to be further activated by other stimuli. A second stimulation of EB-activated HPMN, by PMA and Zymosan, was previously shown (Zvillich \& Sarov, 1985). The different patterns of the CL response induced by EB and EB cell walls in the HPMN may be due to some differences between the number of EB and EB cell walls employed, and/or due to differences in surface characteristics between the EB and EB cell walls. Differences in the CL response of HPMN to infection with different strains of Klebsiella pneumoniae, due to cell wall differences, have been observed (Robinson et al., 1984). 


\section{DISCUSSION}

In the present study we have analysed the possibility that EB cell wall antigens and cell walls persist in HPMN, and have examined their ability to induce a CL response, i.e. the production of oxygen free radicals which might have a role in the aetiology of rheumatic and chronic diseases (Halliwell \& Gutteridge, 1984).

Eissenberg et al. (1983), using indirect immunofluorescence, ferritin labelling of secondary granules and radioisotopic labelling, also obtained evidence indicating the persistence of Chlamydia psittaci EB envelopes in mouse resident peritoneal macrophages as well as in L cells, in the absence of phagosome-lysosome fusion (PLF). However, Yong et al. (1986) demonstrated PLF in chlamydia-infected HPMN by detecting peroxidase-positive phagosomes containing chlamydia. The reason for the lack of degradation of $C$. trachomatis EB cell walls by HPMN after as long as $24 \mathrm{~h}$, in spite of the probable occurrence of PLF, is unknown. It has been suggested that the inability of the HPMN to degrade cell wall components of certain bacteria is due to the presence of lipopolysaccharide, polysaccharide-teichoic acid complexes and certain lipids and waxes which hinder the accessibility of the peptidoglycan to the lysozyme (Ginsburg \& Lahav, 1983). In this regard Rozenberg-Arska et al. (1985) showed, by an electron microscopic study, the rapid killing (15 min after phagocytosis) and degradation of unencapsulated Escherichia coli by HPMN, while encapsulated E. coli resisted killing and degradation by HPMN after $1 \mathrm{~h}$ of incubation. Tamura \& Manire (1968) demonstrated the failure of lysozyme/EDTA to affect the integrity of envelopes of Chlamydia, indicating that they differ fundamentally from those of most bacteria. Further studies are required in order to characterize the degradation-resistant components of $C$. trachomatis cell walls.

Previous studies have demonstrated that EB can induce a CL response in HPMN (Soderlund et al., 1984; Zvillich \& Sarov, 1985). In the present study we have demonstrated that EB cell walls can also induce a $\mathrm{CL}$ response in HPMN (Fig. 5). Superoxide anions $\left({ }^{\circ} \mathrm{O}_{2}^{-}\right)$and hydrogen peroxide $\left(\mathrm{H}_{2} \mathrm{O}_{2}\right)$ are also produced by EB-activated HPMN (Zvillich \& Sarov, 1988). Several Gram-negative bacteria, as well as lipopolysaccharide and the synthetic $N$-formylated methionyl oligopeptide analogous to the $\mathrm{NH}_{2}$-terminal degradation product of bacterial proteins, can induce the production of $\mathrm{H}_{2} \mathrm{O}_{2}, \mathrm{O}_{2}^{-}$and CL by HPMN (Bradley, 1979; Dahlgren \& Stendahl, 1982; Robinson et al., 1984). The chlamydial cell wall component(s) involved in the activation of the HPMN need further characterization.

We suggest that undegraded or partially degraded chlamydial cell walls, exocytosed by phagocytosing HPMN, or translocated by macrophages (Ginsburg, 1977), may accumulate in the joints or tissues, attract (Megran et al., 1985; Petrone et al., 1980) and stimulate HPMN to produce oxygen radicals, which may participate in cartilage destruction directly (Burkhardt $e t$ al., 1986), or indirectly (Lunec \& Hill, 1984; Wickens et al., 1984).

This study was supported by the Middle East Eye Research Institute (MEERI). We thank Dr Moreen Fridman and Galila Green for criticism and help with the manuscript.

\section{REFERENCES}

Abrams, A. J. (1968). Lymphogranuloma venereum. Journal of the American Medical Association 205, $59-62$.

BABIOR, B. M. (1978). Oxygen-dependent microbial killing by phagocytes. New England Journal of Medicine 298, 659-668.

BIBERFELD, P. (1971). On blood lymphocytes activated by phytohaemagglutinin in vitro. Acta pathologica et microbiologica scandinavica (Supplement) 223, 7-8.

Biemond, P., SwaAk, A. J. G., Penders, J. M. A., BeindorfF, C. M. \& Koster, J. F. (1986). Superoxide production by polymorphonuclear leucocytes in rheumatoid arthritis and osteoarthritis: in vivo inhibition by antirheumatic drug piroxicam due to interference with activation of the NADP-oxidase. Annual of Rheumatic Diseases 45, 249-255.

BoYUM, A. (1968). Isolation of mononuclear cells and granulocytes from human blood. Scandinavian Journal of Clinical and Laboratory Investigation (Supplement 97) 21, 77-89.

Bradley, S. G. (1979). Cellular and molecular mechanisms of action of bacterial endotoxins. Annual Review of Microbiology 33, 67-94.

Burkhardt, H., Schwingel, M., Menninger, H., MACARTNEY, H. W. \& TSCHESCHE, H. (1986). Oxygen radicals as effectors of cartilage destruction. 
Direct degradative effect on matrix components and indirect action via activation of latent collagenase from polymorphonuclear leukocytes. Arthritis and Rheumatology 45, 249-255.

Caldwell, H. D., Kromhout, J. \& Schachter, J. (1981). Purification and partial characterization of the major outer membrane protein of Chlamydia trachomatis. Infection and Immunity 31, 11611176.

Cerutti, A. P. (1985). Prooxidant states and tumor promotion. Science 227, 375-381.

DAHLGReN, C. \& STENDAhL, O. (1982). Effect of in vitro preincubation of polymorphonuclear leukocytes on formyl-methionyl-leucyl-phenylalanine induced chemiluminescence. Infection and Immunity 37, 34-39.

Eissenberg, G. L., Priscilla, B. W., Carolyn, H. D. \& RUMPP, J. W. (1983). Chlamydia psittaci elementary body envelopes: ingestion and inhibition of phagolysosome fusion. Infection and Immunity 40 , $741-751$.

Fanburg, L. B., Deneke, M. S., Lee, L. S. \& Hill, S. N. (1986). Mediators of lung injury in oxygen toxicity. In Bronchopulmonary Dysplasia and Related Chronic Respiratory Disorders, pp. 16-23. Edited by P. M. Farrell \& L. M. Taussig. Report of the Nintieth Ross Conference on Pediatric Research. Colombus, Ohio: Ross Laboratories.

GINSBURG, I. (1977). Can chronic and self-perpetuating arthritis in the human be caused by arthrotropic undegraded microbial cell wall constituents? A working hypothesis. Rheumatology and Rehabilitation 16, 141-149.

GINSBURG, I. (1979). The role of lysosomal factors of leukocytes in the biodegradation and storage of microbial constituents in infectious granulomas. In Lysosomes in Applied Biology and Therapeutics, pp. 327-406. Edited by P. Jacque \& J. Dingle. Amsterdam: North Holland.

GiNSBURG, I. \& LAHAV, M. (1983). Lysis and biodegradation of microorganisms in infectious sites may involve cooperation between leukocyte serum factors and bacterial wall autolysis: a working hypothesis. European Journal of Clinical Microbiology 2, 186191.

Halliwell, B. \& Gutteridge, J. M. C. (1984). Oxygen toxicity, oxygen radicals, transition metals and disease. Biochemical Journal 219, 1-14.

Ishikawa, H., OHNo, O., Yamasaki, K., Ikuta, S. \& Hirohata, K. (1986). Arthritis presumably caused by Chlamydia in Reiter's syndrome. Journal of Bone and Joint Surgery 5, 777-779.

JenKIN, H. M. (1960). Preparation and properties of cell walls of the agent of meningopneumonitis. Journal of Bacteriology 80, 639-647.

KEAT, A. C. S. (1986). Chlamydia trachomatis infections in human arthritis. In Chlamydial Infections, pp. 269-279. Edited by D. Oriel, G. Ridgway, J. Schachter, D. Taylor-Robinson \& M. Wan. London: Cambridge University Press.

Keat, A. C. S., Dixey, J., Sonnex, C., Thomas, B., OSBORN, M. \& TAYLOR-RoBINSON, D. (1987). Chlamydia trachomatis and reactive arthritis: the missing link. Lancet, January 10, 72-74.

KEISER, D. H. (1980). The effects of lysosomal enzymes on extracellular substrates. In The Cell Biology of
Inflammation, pp. 431-437. Edited by G. Weissman. New York: Elsevier/North Holland Biomedical Press.

Kunimoto, D. \& Brunham, R. C. (1985). Human immune response and Chlamydia trachomatis infection. Review of Infectious Diseases 7, 665-673.

LADANY, S. \& SAROV, I. (1985). Recent advances in Chlamydia trachomatis. European Journal of Epidemiology 1, 235-256.

LAEMMLI, U. K. (1970). Cleavage of structural proteins during the assembly of the head of bacteriophage T4. Nature, London 227, 680-685.

LEVY, J. N. \& MouldER, J. W. (1982). Attachment of cell walls of Chlamydia psittaci to mouse fibroblasts (L cells). Infection and Immunity 37, 1059-1065.

LUNEC, J. \& HILL, C. (1984). Some immunological consequences of free radical production in rheumatoid arthritis. In Oxygen Radicals in Chemistry and Biology (Proceedings, Third International Conference, Neuherberg, Federal Republic of Germany), pp. 939944. Edited by W. Bons, M. Saran \& D. Tail. Berlin \& New York: Walter de Gruyter.

Lunec, J., Halloran, S. P., White, A. G. \& DoRMANDY, T. L. (1981). Free-radical oxidation (peroxidation) products in serum and synovial fluid in rheumatoid arthritis. Journal of Rheumatology 8, 233-245.

Megran, D. W., Grant Striver, H. \& William, B. R. (1985). Complement activation and stimulation of chemotaxis by Chlamydia trachomatis. Infection and Immunity 49, 670-673.

Mohr, W., Kohler, G. \& Wessinghage, D. (1981). Polymorphonuclear granulocytes in rheumatic tissue destruction. II. Demonstration of PMNs in rheumatoid nodules by electron microscopy. Rheumatology Internal 1, 21-28.

Monnickendam, A. M. \& Pearce, J. H. (1983). Immune response and chlamydial infection. British Medical Bulletin 39, 187-193.

Monnickendam, A. M., Darougar, S., Treharne, J. D. \& Tibury, A. M. (1980). Development of chronic conjunctivitis with scaving and pannus, resembling trachoma, in guinea-pigs. British Journal of Ophthalmology 64, 284-290.

MOULDER, J. N. (1982). The relation of basic biology to pathogenic potential in the genus Chlamydia. Infection (Supplement 1, review) 10, 1-9.

Pasquier, C., Mach, P. S., Raichvarg, D., Sarfati, G. \& AMOR, B. (1984). Manganese-containing superoxide dismutase deficiency in polymorphonuclear leukocytes of adults with rheumatoid arthritis. Inflammation 8, 27-32.

Petrone, W. F., English, D. K., Wong, K. \& MCCORD, J. M. (1980). Free radicals and inflammation: superoxide-dependent activation of a neutrophile chemotactic factor in plasma. Proceedings of the National Academy of Sciences of the United States of America 77, 1159-1163.

Quie, P. G., Mill, L. E. \& Holmes, B. (1977). Molecular events during phagocytosis by human neutrophils. Progress in Hematology 10, 1-9.

Robinson, P., Wakefield, D., Breit, S. N., Easter, J. F. \& PENNY, R. (1984). Chemiluminescent response to pathogenic organisms: normal human polymorphonuclear leukocytes. Infection and Immunity 43, 744-752. 
Rozenberg-Arska, M., SAlters, M. E. C., van SriJp, J. A. G., Geuze, J. J. \& Verhoef, J. (1985). Electron microscopic study of phagocytosis of Escherichia coli by human polymorphonuclear leukocytes. Infection and Immunity 50, 852-859.

SAlARI, H. S. \& WARD, E. M. (1981). Polypeptide composition of Chlamydia trachomatis. Journal of General Microbiology 123, 197-207.

SAROV, I. \& BECKER, Y. (1969). Trachoma agent DNA. Journal of Molecular Biology 42, 581-589.

SHEMER, Y. \& SAROV, I. (1984). Inhibition of growth of Chlamydia trachomatis by human gamma interferon. Infection and Immunity 48, 592-596.

SOderlund, G., Dahlgren, C. \& Kihlstrom, E. (1984). Interactions between human polymorphonuclear leukocytes and Chlamydia trachomatis. FEMS Microbiology Letters 2, 21-25.

Storz, J. (1967). Psittacosis agents as cause of polyarthritis in cattle and sheep. Veterinary Medical Review 2/3, 125-139.

TAFFEL, A. L. (1973). Lipid peroxidation damage to cell components. Federation Proceedings 32, 1870.

TAMURA, A. \& Manrie, G. P. (1968). Cytochrome $c$ reductase activity of meningopneumonitis organisms at different stages of development. Proceedings of the Society for Experimental Biology and Medicine 129, 390-393.

Trush, M. A., Wilson, E. M. \& VAN DYxe, K. (1978). The generation of chemiluminescence (CL) by phagocytic cells. Methods in Enzymology 57, 462494.
Wickens, D., Norden, A. \& DORMandy, T. (1984) Effect of free radical activity on tryptophan and human gamma globulin. In Oxygen Radicals in Chemistry and Biology (Proceedings, Third International Conference, Neuherberg, Federal Republic of Germany), pp. 754-756. Edited by W. Bons, M. Saran \& D. Tail. Berlin \& New York: Walter de Gruyter.

WoOdland, R. M. \& Darougar, S. (1986). Feline keratoconjunctivitis - an animal model of persistent chlamydial conjunctivitis. In Chlamydial Infections, pp. 412-415. Edited by D. Oriel, G. Ridgway, J. Schachter, D. Taylor-Robinson \& M. Ward. Cambridge: Cambridge University Press.

Yong, C. E., ChI, E. Y., Chen, W. J. \& Kuo, C. C. (1986). Degradation of Chlamydia trachomatis in human polymorphonuclear leukocytes: an ultrastructural study of peroxidase-positive phagolysosomes. Infection and Immunity 53, 427-431.

ZVILLICH, M. \& SAROV, I. (1985). Interaction between human polymorphonuclear leukocytes and Chlamydia trachomatis elementary bodies: electron microscopy and chemiluminescent response. Journal of General Microbiology 131, 2627-2635.

Zvillich, M., Kol, R., RIRLIS, E. \& SAROV, I. (1988). Induction of DNA strand scissions in HeLa cells by human polymorphonuclear leucocytes activated by Chlamydia trachomatis elementary bodies. Journal of General Microbiology 134, 2405-2412. 